\title{
Political Instability and Economic Growth in the State of Yemen: Analysis Study
}

\author{
Ph.D. Candidate: Najeeb Alomaisi \\ German University of Administrative Science \\ E-mail: nalomaisi@yahoo.com or najeeb.alomaisi@stud.uni-speyer.de
}

Received: Jan. 28, 2020 Accepted: May 19, 2020 Online published: June 2, 2020

doi:10.5296/jpag.v10i2.16311 URL: https://doi.org/10.5296/jpag.v10i2.16311

\begin{abstract}
This paper explores the drivers of political instability and how political instability affects the economy in the context of Yemen. It is a low country income, although the critical location is at the southern end of the Arabian Peninsula with 200 islands. The country is rife with terrorists and lives under much socio-political strife. We implemented an empirical model to test the correlations and multiple regression between political instability and economic growth. The study found that there is a high negative correlation between volatility and economic growth with negative correlations value. Furthermore, we investigate the significance of the regression -enter method- stepwise method which show the existence of the impact of the political instability index conflict, and civil war in economic growth.
\end{abstract}

Keywords: political stability, economic growth, conflict, civil war. Hothies, Arab Spring, foreign intervention

\section{Introduction}

Yemen is one of the poorest countries in the Arab region. Its poverty is not because of a lack of resources, but rather, the result of instability and conflicts. The country has been engaged in civil war since March 2015, which has a substantial, negative impact on people's daily life. In addition to poverty, the economy is fragile, and corruption is high. Since the Arab Spring crises of 2011 Yemen's society still suffers from the consequences. For example, in 2006 the poverty rate was at $34 \%$ but has since risen to an estimated $82 \%$ since 2017(World, 2017). The numbers of those in need of humanitarian help increased from 18 to 22 Million. In 2016 United Nations, announced that approximately eight Million people were reached with emergency cash as part of a transfer project between UNICEF and the World Bank.

Hundreds of children were killed in the war while the remnant millions face a cholera epidemic, looming famine, a disruption in health services and a blockade hampering delivery 
of much-needed supplies. Although since 1995 Yemen started financial, managerial, and economic programs with support from the World Bank and donor nations, the programs have failed to meet the goals as planned, according to (Almutawakel, 2014), a professor of economics. Also, the shift from the two emerged economic systems from south and north to a free market financial system does not meet the goals, because this shifting period was conducted and followed by unstable conditions (Alesina et al., 1996; Jong-A-Pin, 2009).In this paper; we will seek to identify the impact of political unrest and violence on economic growth over the decades in Yemen. Why this study about Yemen? First, no empirical research has yet been done considering quantitative data to estimate the influence of political instability and violence in Yemen's fragile economy. Second, Yemen's does not benefit of the location on the Arabian Peninsula includes a sea road because of the conflict and instability. The Arabian and Red seas in Bab Al Mandab through which almost 4.7 million barrels of oil pass every day, to the rest of the world.

After the unification of Yemen, many challenges were boosted. South-Hirak, southern Yemenis who felt they are marginalized after unity, so they start asking for equal treatment and their rights since 2007, end up with asking for secession forming new Southern Transitional Council, and, Al-Qaeda in the Arabian Peninsula (AQAP) and the related Ansar Al-Sharia who was active after 2000. Thirdly the Hothie group in North of Yemen who believe in their right as a holy group and want to restore the right to govern, they raised up against Saleh regime six times. Finally, they take over the capital, force the government of national reconciliation and president Hadi to leave escaping to Aden then to Saudi Arabia, forming a new ally with former president, who was killed from the Hothie group accused him of betraying. With all, the challenges we can't ignore the difficulties of being democratic in the region and try to go ahead facing the greedy neighbours who thinks they will be affected if the democratic regime succeeds in the region.

Instability in Yemen can be observed because of conflict and violence about political authority and control over resources. Uncertainty has been ongoing for hundreds of years. However, Yemen was not stable even after the revolution of 1962. Since then, yet, more than 13 civil wars have occurred, all fought over power and resources. In 1990, Yemen turned to a democratic system to take a difficult path to stability. Yemen struggled to adapt to changes happening around the world in terms of the global economic system, political and administrative systems, but instability obstacles hampered any progress. Recently, the Hothie Movement killed President Saleh after three years of war and then took power from the legitimate president Hadi. Thus, as a result of conflicts, internal civil war, external intervention from neighbouring countries and international intervention from economic interests in the region, Yemenis dreams to achieve stability remain unfulfilled.

In this work, we will refer to political events in Yemen before the revolution of 1962 and focusing in the period from 1990 until now, and also the events of the region, which affect political stability in Yemen and lead to its vulnerability. Political stability (PS) variables are intended to measure political instability that influences the economy through increasing uncertainty, which reduces investment opportunities. The PS index (Kaufmann et al., 2011) includes the following variables: government stability, internal conflict, external conflict, and 
sectarian tensions, tribal and ethnic tensions. Various authors use different indicators of political instability. This paper will examine the influence of political instability on current economic conditions in Yemen to identify and highlight the causes of continuous unrest. We argue that ongoing instability and conflict which have three contributors - local, regional and international - because of power struggles over power and economic interests in the region.

\subsection{Study Contest}

The study mainly seeks to explore the influence of instability in the economy GDP. The indicators represented instability, as indicated by the World Bank are civil, local, regional, ethnic, and religious conflict as showing in figure (1).

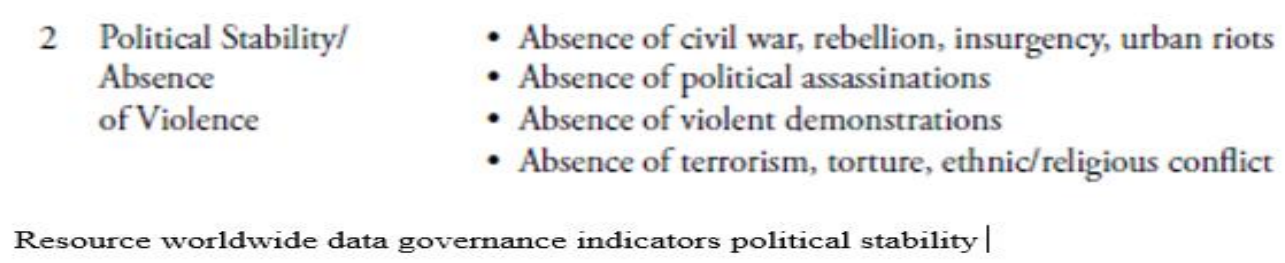

Figure (1).

We can derive specific sub-questions about Yemen. Like, what are the real drivers of instability in Yemen, how they are related to the economy? How we can find an answer to the cause of Yemen's political instability and ongoing political events.

\section{Literature Review}

\subsection{Introduction}

Literature and experience have shown a very connected link between political instability and economic growth. Yemen is an added example to the previous model of Sudan, Afghanistan, South Sudan, Syria, Iraq, and Libya. Dramatically, events since March 2015 makes Yemen faces the most ever sever socioeconomic deterioration; In the recent report Food and Agriculture Organization (FAO) the political situation result until 2017 more third of population suffered the famine, and Cholera, outbreaks continue to ravage the country. Four hundred fifty thousand persons were suspected of having affected by the Cholera virus and 2000-death case in 2018 (World, 2017). The conflict has its influences in both economic and social life. Such example, $41 \%$ of enterprises laid off $55 \%$ of their workforce. The consumer price increased sharply, and the government cannot pay salaries since October 2016, beside the rest of the private sector reduced the monthly instalment for workers. Many undertaken empirical studies emphasize the effect of instability in the economy. We will elaborate below.

\subsection{Empirical Review}

Most studies suggest that political instability has a negative influence on economic growth. The traditional meaning of stability refers to liberal government or long-term democracy or dictatorship. The definition has changed to meet development needs, and stability refers to the efficiency and consistency of stable government. Besides, political instability causes 
uncertainty and reduces investment, which negatively influences economic growth. The pattern of government policies and spending directly affects economic growth. Political instability negatively impacts investment locally and internationally because it is difficult to invest in a country with a low instability rate. Furthermore, the terrorist attacks in Yemen make the socio-economic situation worse.

Siermann, 1998 defines political stability as the assumption of weak government approach also used by journalists to indicate weak governance. In Yemen, initiating investment and new business are connected to political stability. Much effort went into minimizing the length of time needed and procedures to start businesses because they are two factors that are part of the index of healthy regulation policies necessary to sustain a country's economy. Moreover, the new investment law of 2002 was designed to facilitate and attract external and internal investment. Many external and internal political events happened after the unification of Yemen. The miracle of Yemen's unification was considered as President Saleh's positive achievements. After unification and the merging of two economic systems, reforms were announced for adapting the new system, which was called a change from government to governance. New policies were established, the democratic system was approved, and the new constitution was put to a referendum. The free market economy started, but many political events, violence, and war, of course, interrupted its progress. Investors will not risk investing in a country full of hazards and well known for upheaval. Thus, the result is that normally political instability will negatively influence investment, which negatively influences the whole economy. Thus, many studies find that political instability effects economic. Political instability intensifies physical capital and hinders the GDP income. The lack of political stability in Yemen has led many Yemenis to lose their jobs, and the largest group of youth are jobless. Many empirical and theoretical literature has shown instability negatively affects economic growth (Alesina et al., 1996; Benhabib \& Spiegel, 1994; Easterly \& Rebelo, 1993; Tabassama et al., 2016). Researchers have argued that political instability results in less investment, high rate of inflation, and less volume of employment and productivity, which in turn slows economic activities.

Other researchers see, political instability results in a drop in investment, which affects the overall economy (Barro, 1991; Rodrik, 1989; Schneider \& Frey, 1985; Tabassama et al., 2016). Furthermore, some economists (Alfaro et al., 2008; Busse \& Hefeker, 2007; Daude \& Stein, 2007) have indicated that political instability often cuts foreign direct investment; (Aisen \& Veiga, 2005; Cukierman et al., 1989), which may cause high inflation rates. Moreover, it has been noted that when there is no instability, there is no protection to investor's property rights due to the loss of the state control. For example, some countries have all resources but lack stability because of Terrorism, strikes and civil unrest causes an unstable government regulation and policies (Tornell \& Velasco, 1992). In 2015 United Nations, declared that unsuitability weakness the state rule of protecting investors and properties.

Many other studies have also documented the adverse effect of political instability on economic growth. These economists have argued that political instability reduces the volume of investment, increases inflation, and reduces the amount of employment and productivity, 
which in turn slows economic activities. Edward Haddad, 2005 argued that the first challenge when seeking to improve Yemen's business sector is economic instability, which results from political instability derived from changes in government and the absence of long-terms programs (Edward, 2005).

\subsection{Local, Regional Events Conflicts Events in Chronological History Related to Instability in Yemen}

This collected data from different resources by the researchers. All these events have direct or indirect effects on the political and economic instability in Yemen.

Table (1). Political unrest and conflict 1994 till Now

\begin{tabular}{|c|c|}
\hline Event & Year 1990 till now \\
\hline Separation war & 1994 \\
\hline War against terrorism & 2000 till now \\
\hline First Sa'dah war & 2004 \\
\hline Second Sa'dah war & 2005 \\
\hline Third Sa'dah war & 2006 \\
\hline Fourth Sa'dah war \& and southern Hirak & 2007 \\
\hline Fifth Sa'dah war & 2008 \\
\hline Six Sa'dah war & 2009 \\
\hline Arab spring and Islah party with hothies ,Sanaa invasion & 2011 \\
\hline Arab Allies war in Yemen and & 2015 till now \\
\hline
\end{tabular}

\subsection{Definition: Political Instability}

Political instability is the "capturing perceptions of the likelihood that the government will be destabilized or overthrown by unconstitutional or violent means, including politically "motivated violence and terrorism.”(Kaufmann et al., 2011)

\subsection{Political Events Influence Stability of Yemen}

\subsubsection{Imamate Era Pre 898 AD -1962 AD}

The Imamate Era began in north Yemen in $898 \mathrm{AD}$ with the invitation of Yemeni tribes due to the conflict in north. Imamates was expanded to the south too. This gave Imam Hadi Yahiya bin Al Hussein an excellent chance to establish the Zaydi. Then imamate continues governing Yemen through religious power and bloodshed, thousands of Yemenis .were killed until the 1962 revolution which brought about the collapse of the Imamate.

This period also witnessed conflicts between the Imams themselves over authority and resources. As a result of the absence of political and economic institutions saw Yemen isolation from the world resulting in low living standards. Although the revolution came in 1962, the idea of an Imamate remained, because the ideology ethnically rooted in the beliefs of Imams families such as Hothies. Al-Hothie Group Zaydis, one Sect of Shi'a and Zaid a son Imam Zaid Bin Ali and all are descendants of Imam Ali, but Zadie's sect is a more close to Sunna, but Hothie has changed the ideology following the practice of Shi'a Iran. 


\subsubsection{Yemen After the Revolution 1962 and 1990 and so on}

Unification of the country until now:

Yemen's history shows that it has not experienced long periods of stability before unification in 1990 see figure (1). Yemen has experienced considerable political unrest since the revolution with changes to political authority the result of using military force either against the south or north. The only stable period was in between 1995 to 2004. After the civil war of separation, democracy was announced as the new system. Following this development was the surplus in the general budget in the year 2000. The unification was successful despite the opposition by Yemen's neighbouring countries.

Many problems arose because of the impropriety of events that accompanied unification, such as the retirement of some military soldiers from the south and ignoring the challenges of integrating two different economic systems and so many issues were not solved to establish the new state.

Starting the democratic process guaranteed stability regarding the legitimacy of the government until the events of 2011 led to Saleh's resignation and the subsequent artificial election of Hadi. Some politicians consider these later events in Yemen as a threat to the fledgling democracy. Specifically, when the Al-Hothie group captured the governing authority and installed Hadi in the presidency, and the government left the country escaping to the Saudi Arabia Kingdom (KSA).

Political events in the region cannot be ignored as a setback to the economic fragility. Interventions from regional countries, such as the KSA and the United Arabic Emirates, had a substantial effect on the region's reforms and stability.

More so, the challenges of regional failure states worsened the situation, the refugee crises from Somalia, and Ethiopia seeing more than 50000 finding refuge in Yemen. The problem of piracy in Africa horny lead to avoiding Yemen's ports by international shipping firms to avoid piracy or they should pay more insurance cost.

\subsubsection{Terrorism Negative Impact on the Economy}

Several studies view terrorism as a result of tensions and competition over new resources. Terrorism has had some considerably damaging people utility. Terrorism is one index of instability causes economic slowdown and negatively affects growth (Ranga \& Pradhan, 2014). Terrorism is one of the significant causes of instability in Yemen, with severe and harmed influence on the Yemeni economy. Terrorist propaganda resulted in the departure of capital and labels, ever since Yemen was considered a terrorist country. The government was further found guilty of abuses in the war against terrorists during Ali Saleh regime, especially toward the opposition.

On the other hand, others insisted Al Qaeda was a tool of Saudi Arabia to worsen the condition in Yemen. The Saudis have long supported the Imam against the revaluation and paid some tribes to keep the lands that belong to Yemen, and Saudis supported the failed secession in 1994 (AlMayadeenNews, 2015) in reaction to Yemen's in 1994 in reaction to 
Yemen's stand with Iraq in 1990. As retribution, Saudi Arabia sent back more than one million Yemeni workers, which caused a great shock to Yemen's economy. The relationship later however stabilized, in 2000 Saudi Arabia and Yemen reached the border treaty. Then the Saudi new strategy against Yemen began with export terrorism and depict Yemen as a terrorist country.

In 2009, it was called the strategy of fighting terrorism changing the name of Al Qaeda in the region to Al Qaeda in the Arabian Peninsula (AQAP). Many terrorist attacks happened in Yemen, which reflect a dark view about the country and caused Yemen to lose many chances to improve the economy by attracting foreign investments or at least have good relations with the world. After the Arab Spring and fall of the Saleh regime, Yemen continued to deal with the United States in fighting against terrorism. In 2012, Yemen's ministry of defence in Sana'a was attacked resulting in 30 deaths of military personnel. The investigation found that seven of the attackers were from KSA. The exported terrorism and other conspiracies to disrupt Yemen's resources worsened then situation, a case in point is the, supporting of Sallifeen in Sa'dah. More so religious group from the north of Yemen faced the Zaidi sect and depicted Yemen as a source of threat to world peace and tarnished its image and reputation on a global scale. The issue of the parcels in 2010, sent to Dubai and England going to the United States; When the Yemeni government accused the game of dirty intelligence to implicate Yemen in the case of parcels parcel, saying why Saudi Arabia did not report to Yemen before reporting it to America. Another issue refers to Al Qaeda members executing many terrorist attacks, which affected the tourist sectors, investment, and national capital in Yemen. For example, for every dollar spent on aid in Yemen between 1990 and 2008, another $\$ 2.70$ left the country (Hill et al., 2013).

The USA further responded by military strikes, the repeated breakthrough the Yemeni airspace under the pretext of terrorism. The airstrikes had many casualties especially innocents' victims. This disregard of Yemen sovereignty further isolated Yemen yet the country was a partner in the war against terrorism. This misconception should qualify the USA missions to only provide logistical support and counselling to avoid further reactions and discontent. Especially the issue of terrorism in the region is considered formula and deception imposed and conspiracy to further acquisition and the extension of influence. Although terrorism exists everywhere, Yemen is a victim and not a criminal. Yemen has suffered from the scourge of terrorism and has been struck hard and can curb the phenomenon instead of cheap exploitation.

Figure (2)

Sources: (Sharp \& Brudnick, 2015)

\subsubsection{Yemen After What So-Called Arab Spring}

After the Arab Spring protest, the political situation did not change, and Yemen has not ever since seen stability. The socio-political situation has escalated from bad to worse; this is reflected in the deplorable life situation of Yemenis. The former president signed the Gulf Counsel Countries (GCC) initiative, and a new president was elected in an initiative that is 
said to have been coined by the former Yemeni president Saleh, who was aware of the fear of a return of imamate era and assassinations after the transition to democracy. Sure to his fears in 2017 was assassinated from the Hothies group.

Later on, the Hothie group exploited the conflict between elites and parties fighting, and it infiltrated in the name of its oppressor and was further involved in the dialogue. The Yemeni government had to apologize to the Hothie group of the sixth Sa'dah wars. The disruption of civil and military institutions and the exchange of accusations and armed confrontations with an economic crisis accompanied by the former president Saleh accused Saudi a Arabia was behind the disruption of the army and demobilization exercise, exploiting the Yemeni dispute. Saleh accused Saudi Arabia directly in more than a press interview. Saudi Arabia Kingdom (KSA) is seeking to expand and achieve ambitions to take many things not previously agreed upon. He accused KSA of killing Ibrahim Alhamdi previous president after Yemeni revaluation 1962. While the dialogue was going, the Houthi group was expanding and sweeping the cities until dropping the province of Amran closest to the capital. The group managed to bring down the Sanaa after the recommendation by the World Bank to the Yemeni government to address the crisis of budget deficit by lifting oil derivatives. The Houthi distressed the people and besieged the President, the government and then dropped the Sanaa announcing his first statement. President Hadi to several reserves in southern Yemen, which allowed starting the battle to restore the legitimacy in March 2015.

Arab Allies named the battle Asifah AlHazm after he sensed the danger of the Al-Hothies group he resorted to battle escapades at border Yemeni-Saudi Arabia even up to as late as 2018. Yemeni government is subjected to an ongoing war backed by the Arab alliance, which is surrounded by doubts and many see that it has agendas. The Hothie were able to face internal and external judgments for up to four years until the writing of this paper. The assassination of the former president Saleh was in December 2017. No one has claimed responsibility for this assassination, but it is highly possible that there is an external hand, linked to the Hothies. Saleh death shocked the Yemeni and Arab nation and exacerbated the crisis and intensifying the conflict because Saleh was representing with the General People's Congress Party (GPCP), which he headed after his resignation as a solution to the crises in Yemen. All these endless confrontations and perpetual conflict impeded productivity, transitioning to famine. The United Nations categorized these events as the greatest contemporary humanitarian crisis.

The figure below reflects the loss of state control due to interventions and political unrest. The government was further weakened, and its legitimacy became porous every day. This and has created a fertile environment for many opportunists to carry out external projects such as the Saudi and Saudi and internal authoritarian projects such as the Houthi group and southern Hirak, which resulted in creating the Southern Transitional Council (STC) who is calling for independence. Due to the absence of state role and the failure of the coalition in the restoration of legitimacy and this is what Yemenis fear. 


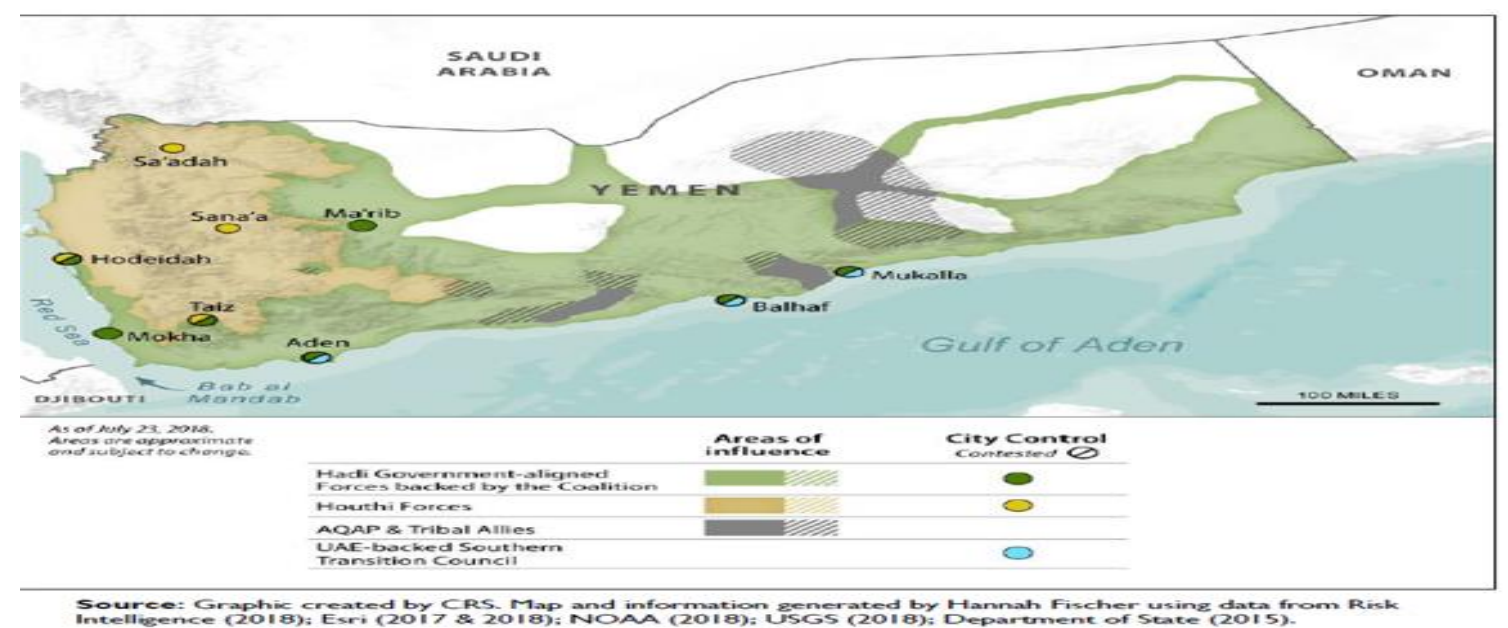

Figure (3). Segregation of the country

Resources, (Sharp \& Brudnick, 2015)

The Intervention of Saudi Arabia and the United Arab Emirates, and Iran in Yemen.

\subsubsection{Saudi Arabia Kingdom}

Saudi Arabia and the United Arab Emirates (UAE) interests in intervention into Yemen's domestic affairs is for their benefit(Hill \& Nonneman, 2011). For example, Saudi Arabia supports some religious groups involved in the religious conflict in Sana'a between Sunna and Shia (Hothie group). More so since 1980, Saudi Arabia has been keen to impede Yemen's discovery of oil, and continues to constantly continually manipulate the Yemeni workforce to pressure the Yemen government to prevent oil and gas development (Alalam, 2015). The UAE controls the port of Aden to prohibit Yemen's interests in favours of Dubai Ports. All these intrusions into Yemen have debilitated its economy, which in cascades to political instability.

There is also an ambiguous relationship between Yemen and Saudi Arabia, it's purported that "King Abdul-Aziz said before his death, indicating fears that a strong Yemen could prove a major threat to domestic Saudi kingdom". According to many Yemeni politicians, Saudi Arabia plays a negative role in Yemen's instability. Saudi Arabia gave 150 Million to some Schick and officers from Yemen (CNNarabic, 2012; Yemenpressagency, 2018). KSA has been against the unification of Yemen in 1990, and almost one million Yemeni immigrants were sent back because of the Gulf War after Iraq invaded Kuwait. The Gulf Country Counsel (GCC) countries were looking to Yemen as a threatening source to the region. GCC has funded hospitals, roads, and schools in Yemen, yet only Kuwait did not put conditions on the funding. The other countries like Saudi Arabia and the United Arab Emirate (UAE) conditioned their funding for personal gain.

Furthermore In support of secession between south and north feud in 1994 monthly payment to some tribes to oppose the government. In 2009, Saudi Arabia participated in the fighting Hothies group. In 2015 KSA led Arab allies to protect itself from Iranian competition in the region. KSA claimed that it was military intervention to aim at restoring the legitimacy of 
Hadi. Yemen seems to be a victim of the cold war between interested regional and international nations specifically Iran and KSA.

\subsubsection{United Arab Emirates Interests in Yemen}

UAE interests in weakening Yemen's through conflicts are not new and did not arise alongside the chaos revaluation or crises of the Arab spring, but instead, are as old as the establishment of the Dubai port group. Thus, they have worked diligently since 2004 to disable Yemen's ports either by smiles as they did before the Arab spring when they paid the rent for the port for an unfair amount when compared with deals offered by KGL Kuwait port, or by weapons as they have since the war against Hothie in cooperation with KSA in 2015. They make camps and control all ports, including Socotra and Medi, which are close to Bab Almandab, a strategic crossing for all ships and oil from the Middle East: approximately 4.8 million gallons of oil are shipped daily. Consequently, Yemen found the contract with Dubai for the Yemen port Aden designed to prevent Yemen from competing with Dubai's port. UAE is not as interested in Yemen's war from a political power perspective as much as it is for economic gain. The UAE is interested in port cities of Aden and Al-Hodeida, and oil-rich cities in Marib. The UAE's goal in Yemen is geostrategic, meant to reinforce UAE's economy, these interests is illustrated by explaining what happened in Aden in 2015 and Socotra in 2018, which are both port cities(Cruz, 2018)

\subsubsection{Qatar Role in Yemen Cries}

Qatar's rule in Yemen was clear in its support of the Al. Islah party as adopted part of the Muslim Brotherhood, but not Al- Hothies, only after the Sa'dah fourth war with Hothie when Qatar became involved to stop the war as a mediator. Qatar offered $\$ 600$ million to the Yemen government. In 2007, Amir Hamad bin Khaliah visited Yemen and donated \$500 million to Sa'dah reconstruction resulting in a ceasefire. The agreement was made in Doha in 2008 between the representative of Government and the Hothies. When the ensuing of the truce reached, Qatar again sent envoys to try to end subsequent conflicts - including the sixth war, in which Saudi Arabia was an active participant. Yemen's Arab Spring led Saleh to order the Qatari Ambassador in Yemen to get out of the country, Accusing Qatar of conspiracy against the regime in Yemen. When the Arab Spring started in 2011, Qatar was supporting the Muslim Brotherhood in different countries, such as Tunis, Egypt and Yemen. In Yemen, Aljazeera channels in Arabic and English were proactive, opposing the regimes in those countries. According to Yemeni officer (Alwals, 2017) the relationship between Qatar and the Hothie started before the Sa'dah sixth war and continued from 2000 to now. In 2007 Qatar was officially announced as a mediator, Buhibeh said that, since 2000, Qatar has provided Hothies with the monthly financial support of $\$ 50000$.

The support was increased in 2008 to $\$ 100000$. Buhibeh also declared that Qatar has worked with Iranian intelligence to coordinate all aspects of support for Hothie Movement. Qatar and Iran have introduced a modern military communications system to Sa'dah including a night telescope and equipment for the manufacture of explosives, mines, missiles and intermediate missiles and the development of artillery projectiles and in many other areas. Through the Iranian company Parasian, from 2007 to 2009 they aided in building a gas conversion station 
and this subject is known to many state officials and some are currently leaders but cannot talk too much because of the impact of gifts and money from Qatar, but everything is clear to those concerned. Finally, some actives of GPCP Qatar play a fatal role in Saleh's assassination in late 2017. The GCC announced that Qatar had connected with many terrorists, including Al-Qaida, in many countries. Subject to a blockade of the GCC and Yemen because of its involvement in the financing of terrorism and its relationship with persons belonging to Al Qaeda AQAP.

\subsubsection{Tehran Role in Yemen Crises}

Iran's involvement in Yemen is not fully documented, as such the Yemen government has long accused Iran of backing the Hothies. Some claim Iran's interests date back to 2007 the very year in which the government accused Qatar of having links to Iran and its support of the Hothies. In 2009, Tehran was accused of transporting 48 tons of weapons by ship. Financial Times newspaper reported in February 2014 that a Yemeni official was claiming that Iran and its Lebanese of supporting Hothie group in proxies. President Hadi in a lecture at the Wilson International Center in Washington, DC, on Sept. 28, 2012, claimed that Iran, want to apply the Iranian experiment in Yemen influencing the south and north (Hournews, 2012). Additionally, Yemeni and Western officers accused Ali Salem Al-Beidh, past president of the south before the unification of connecting with Iran (Salisbury, 2015)

Tehran restricted it connect to Hothies only with sympathy. However, in 2011 the government of Yemen seized a boat with weapons from Iran and in 2012, approximately 900 rockets entering Yemen as military support to Hothies. In 2013 Yemen security announced seizing an Iranian ship named (Gihan1). In 2014, it was reported, Ali Akbar Velayati, expressed Iran real perspective toward Hothie; supporting Hothies rightful struggles as a minority. Also, Ali Reda Zakani, in Khamenei deputy in the local press in Iran, considered a takeover of the capital of Yemen Sanaa as a victory, adding that Iran now controlled the fourth capitals Sana'a (Salisbury, 2015).

\section{Internal Tension and Conflict in Yemen}

The historical events in Yemen highlight that political and economic instability influence life and well- being. The ongoing conflict over political authority which dates back to over 1000 years cascades to contemporary weak political and economic institutions.

\subsection{Sa'dah Issue}

Sa'dah issue was one of the national dialogue March 2013 agenda. AL-Hothie group is an extension to the era of Zaydi Imamate in Yemen 898-1962 overseeing years of political conflict and social injustice. The Al-Hothie Group Zaydis come from the sect which was created by Imam Hussein Ibn Alhadi to categories as new Zaidi doctrine manipulating Yemenis passionate to relatives of the prophet Mohammed. It is, as a similar practice to Sunni sect. The group emerged in 1962 then rose to prominence after 1990 with Al-Haq party representing the Zaydis. The last leader of the group is Hussein Bader Aldin Al-Hothie Son of the founder of the Hothie movement. He was a member of the Yemen Perlman, and he was one of the religious references to the Zaydis sect. He distributed the Zaydis beliefs, teaching 
students who are called the Believing Youth.

In 2004 President Saleh was in Sa'dah coming back from Saudi. He prayed in Al-Hothie Mosque, after finishing the prayers repeated loudly the slogan "God Is Great, Death to America, Death to Israel, Curse on the Jews, and Victory to Islam" president Saleh in anger changed his mind about the group. Al-Hothie responded by withholding their taxes and later attacked the governor and military in the city. President Saleh in vain tried sending envoys to discuss with them and he refused to come, he later extended an invitation to all Zaydis scholars gather and discuss the issue. The gathering condemned the Hothie and said Hothie the group deviated from Zaidi thought. The First war against Hothies was fought in 2004, and the second and third wars destroyed the city of (Sa'dah) leaving ten thousand persons dead. From 2007 Qatar mediated in a bid to resolve the crisis in Yemen. In the 2008 KSA was the involved in the Anti-Hothie war.

In 2011 beginning the Arab spring Hothie group was in the protesting camps in the capital Sanaa against Saleh. Then in dramatic involved in National Dialog Council. At the same time, houses were in confronting with the governments military until entering to capital Sanaa. Suddenly, after outcomes of dialogue announced, there was enacted a transitional government headed by Prime Minister Bahah takes some reform in cooperation with the World Bank to lift subsidies on Oil. Hothies protest against this government because the increased price of Oil. They sweeps the areas with the force of arms confronting the government military and tribes of the Muslim Brotherhood. In July 2014 they took over Imran then in the following two months later took over the capital Sana'a. President Hadi was besieged, but he managed to escape to Aden. After the downfall of Sanaa, Hothies carried out took charge of the Saudi border. The Saudi-led Arab Alliance followed this and began the Battle of Al-Hazm Storm in March 2015.

During this time president Hadi claim of Tehran's involvement in support of the Hothie began when a ship was sent to the group from Iran 2012 and discovered in 2013 In Aden by the Yemen government. In 2016 Saleh announced that any collaboration with Hothie group is aggression. As the war proceeds the Hothie group and pro-Saleh share control of the country. Saleh and Hothies accused each other of corruption and economic mismanagement. Since Saleh has handled the power to president Hadi and loses many options financial and military control. Saleh announced that many times, but all think he still has power. Hothies planned to assassinate Saleh, accusing him of contact with Saudi. Even though in his last speech to Yemeni, he called people for an uprising against the Houthis. He named the Arab alliance "The Aggression". The decision was made to get rid of him, and the assassination was carried assessing him and his Secretary General Aref Alzoka. Now the war against Hothies is in continuation, hence according to UNICEF the situation of Yemen is the worst humanitarian crises in the world.

\subsection{Southern Hirak 2007, and Southern Transitional Council (STC) 2015}

Southern Hirak was founded after the civil war of 1994 according to Ali Salem, the last south president before Unification, and it was only officially declared in 2007. They asked for secession, accusing the government of unfair actions and voiced the need to get their country 
back. The southern movement has demanded independence of south Yemen since July 7 , 2007, which they have since regarded as a country occupied by military force of northern Yemen.

The circumstances have evolved from sit-ins to confrontations in 2007 and 2008. In 2009, Tariq al-Fadhli, leader of the Afghanistan war against the Soviet Union, announced joining the movement. Several incidents occurred in a row, including the burning, killing, and closing of several shops owned by merchants from the north.

The government also accused Salem al-Beid of funding and fighting the unit and therefore detained some active leaders. After 2011 sit-ins, there was a demand for separation and independence (Salisbury, 2014). After the resignation of the former president and the election of Hadi as new president, the desire for independence remained, with factions in the movement joining in the national dialogue in 2013. Included in the agenda of national dialogue was discussions and giving priority to solutions to the two issues of Sa'dah and the southern movement. The Hothie in the north, however, turned against President Hadi and drove him out, causing the fighting from 2015 to the current day. In 2017, the Transitional Council was formed and supported by the UAE. The Transitional Council undermined Hade's legitimacy and expelled legitimacy officers in the new capital, Aden. This confirms that the two issues led to dialogue to gain time and destroy the country by introducing it into endless conflicts as it appears that the president had lost control of the south and the north. Said (Salisbury, 2017), a Senior Consulting Fellow at Chatham, "Yemen was a step closer to becoming a 'chaos state' - a country defined by little more than its borders, in which complex regional conflicts are deepened and prolonged by the interests and actions of external players"

\section{International Intervention in War in Yemen}

\subsection{Yemen at United Nation and Western}

Internationalization of the crisis in Yemen after the Arab spring through. European Ambassadors and USA besides the regional Gulf Council Countries (GCC). All together were involved in GCC initiative about Yemen Sponsored by the United Nations and all the Ambassadors signed. UN envoy Gamal bin Omar as a guarantee to be fulfilled. On 25 April 2015 Bin Omar replaced, and Ismail Ould Cheikh Ahmed was appointed. Although the United Nations Security Council Resolution (UNSCR) 2216 to prevent the transfers to Houthi forces of Iranian-made short-range ballistae missiles, Iran in 2018 was condemned by UN experts report (Sharp \& Brudnick, 2015). Although 2140, 2216, 2402 UNSCRs, UN only express its concern. In 2018 Ismail Ould Cheikh replaced, and Martin Griffiths of the United Kingdom selected. He played a useful role in the humanitarian side, and retry the invitation to Geneva three. Inviting Hothies group and legitimacy crew, but the meeting was cancelled. Despite the grumbling of Yemenis and some observers, the UN tried to bring the disputing sides together but could not enforce any only according to legal steps. At the end of the story, the war in Yemen now called "the forgotten war". The USA and other countries are only concerned with their own interests, and they know that the Hothie group is not international and does not have global effects or threats from the group. The international troops who 
oversee the transfer of Oil and other Shipments maybe the interest of the western countries, the living conditions of the Yemenis is not a priority. The new envoy Martin Griffiths was appointed after the resignation of Ismail Ould Cheikh. This coincided with the situation in Hodeida which got worse especially for the hothies rebels who refused to meet for a political dialogue in Stockholm. Sanaa crew refuse to attend the peace talks. The situation got worse, and the sea road was taken by Hothies control. Then the envoy organized the new meeting in Sweden, known as the Stockholm Agreement in which global and local supported the agreement. This agreement enables UN crew to control Hodeida port. Britain is the sponsor who has submitted a draft to the Security Council about Yemen.

\subsection{Global Peace Index in Yemen}

The war in Yemen has resulted in a spectacular deterioration of economic and living conditions coupled with a sharp Output declined sharply. Yemen peace index going to worse in the global peace index with 158 out 163 nations globally and 18 out of 20 in the Middle East.

\begin{tabular}{|c|c|c|c|c|}
\hline $\begin{array}{c}\text { Regional } \\
\text { Rank }\end{array}$ & Country & $\begin{array}{l}\text { Overall } \\
\text { Score }\end{array}$ & $\begin{array}{l}\text { Score } \\
\text { change }\end{array}$ & $\begin{array}{l}\text { Overall } \\
\text { Rank }\end{array}$ \\
\hline 1 & Kuwait & 1.799 & -0.009 & 42 \\
\hline 2 & United Arab Emirates & 1.82 & -0.071 & 45 \\
\hline 3 & Qatar & 1.869 & 0.206 & 56 \\
\hline 4 & Moracoo & 1.979 & -0.023 & 71 \\
\hline 5 & Orman & 1.984 & 0.052 & 73 \\
\hline 6 & Tunisia & 1.998 & 0.018 & 78 \\
\hline 7 & Jordan & 2.104 & -0.016 & 98 \\
\hline 7 & Algeria & 2.182 & 0.002 & 109 \\
\hline 9 & Saudi Arabia & 2.417 & 0.037 & 129 \\
\hline 10 & Bahrain & 2.437 & 0.002 & 130 \\
\hline 11 & Iran & 2.439 & 0.074 & 131 \\
\hline 12 & Palestine & 2.621 & -0.081 & 141 \\
\hline 13 & Egypt & 2.632 & 0.039 & 142 \\
\hline 14 & Israel & 2.764 & 0.011 & 146 \\
\hline 15 & Lebanon & 2.778 & -0.003 & 147 \\
\hline 16 & Sudan & 3.155 & -0.044 & 153 \\
\hline 17 & Libya & 3.262 & -0.058 & 157 \\
\hline 18 & Yemen & 3.305 & -0.006 & 158 \\
\hline 19 & Iraq & 3.425 & -0.094 & 160 \\
\hline 20 & Syria & 3.6 & -0.061 & 163 \\
\hline \multicolumn{2}{|c|}{ REGIONAL AVERAGE } & 2.529 & -0.001 & \\
\hline
\end{tabular}

Figure (4). Global Peace Index in Yemen

Resource: (GPI, 2018)

\subsection{Yemen Economic Snapshot}

Yemen economy is a primitive economy comes from merging two different economic ideology the socialism in the and free trade economic in North.in 990 the two system merged together under the new Yemen Republic. The economy still suffering from being fragile. The regime since the 1992 could not bring technology and transfer from rentier economy to productive economy, for example, the public budget depends 80 percent on Oil. Yemen export 90 percent of the food security. As result in 2015 to 2017, when economy was stopped GDP was sharply receded with -37 deducted. Instability plays an essential role in investment security and attracting foreign investment. Although many reforms regarding the 


\section{Macrothink}

Journal of Public Administration and Governance

investment law and creation of independent general authority of investment, the rank of new business and investment in the country are at lowest measured countries.

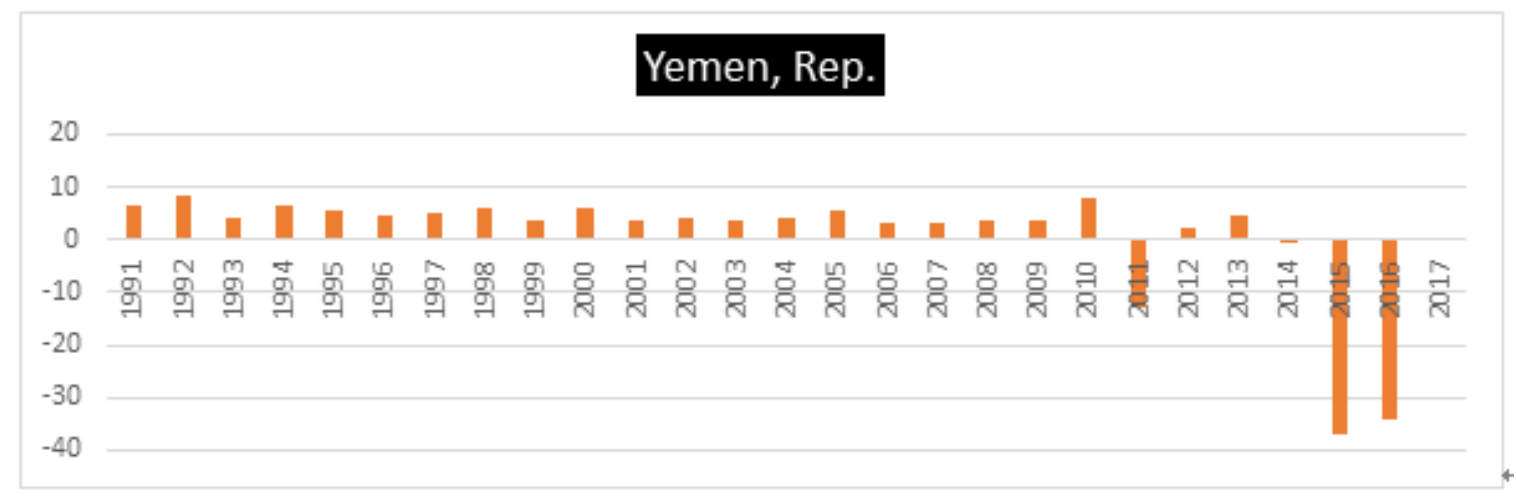

Figure (5). GDP growth declined during conflict

Resource. Estimation (Worldbank, 2017)

The figure above summarizes the deterioration of the economy as Yemen export $90 \%$ of the food. The country budget depends $80 \%$ on Oil, since the escalation of violence and conflict in March of 2015, Yemen's economy deteriorated. There was an exodus of foreign projects, personnel international enterprises left, people in private oil companies lost their employment their works. Yemen's GDP dwindled by 37.5 percent in 2015. Productivity in the country stopped in all sectors including Oil, Gas, fishing and agriculture. This resulted in a cumulative reduction of $40.5 \%$ in the production of goods and services over three years from 2015 to 2017(World, 2017; Worldbank, 2017) Yemen budget depends on the export of oil and gas, which are no longer being exported, the country revenue limited to local tax and customs which leave the government unable to pay civil servants' monthly salaries. Due to absence of the stat and followed by transfer of Central Bank to new capital Aden the inflation increased gradually reaching 600 for one dollar this exerted pressure on the exchange rate, which further undermined household income at a time when approximately $40 \%$ of households reported to have lost their primary income sources(World, 2017). As a result of the downfall of the Foreign Reserves as shown in the figure bellow until 2016. One of the sad news, Yemen does not benefit from its very important resources and location; where Bab Almandab 4 million Gallon Oil daily go the Asia and Europe. In addition, the two-handers and almost 140 Islands .it mentioned by Yemeni people that they sleep in a rich gold country but the eat forks. The researcher thinks depicting Yemen as an instable and home of terrorist and AQPA is meant by some neighbor's countries, who think their interests will be affected. 


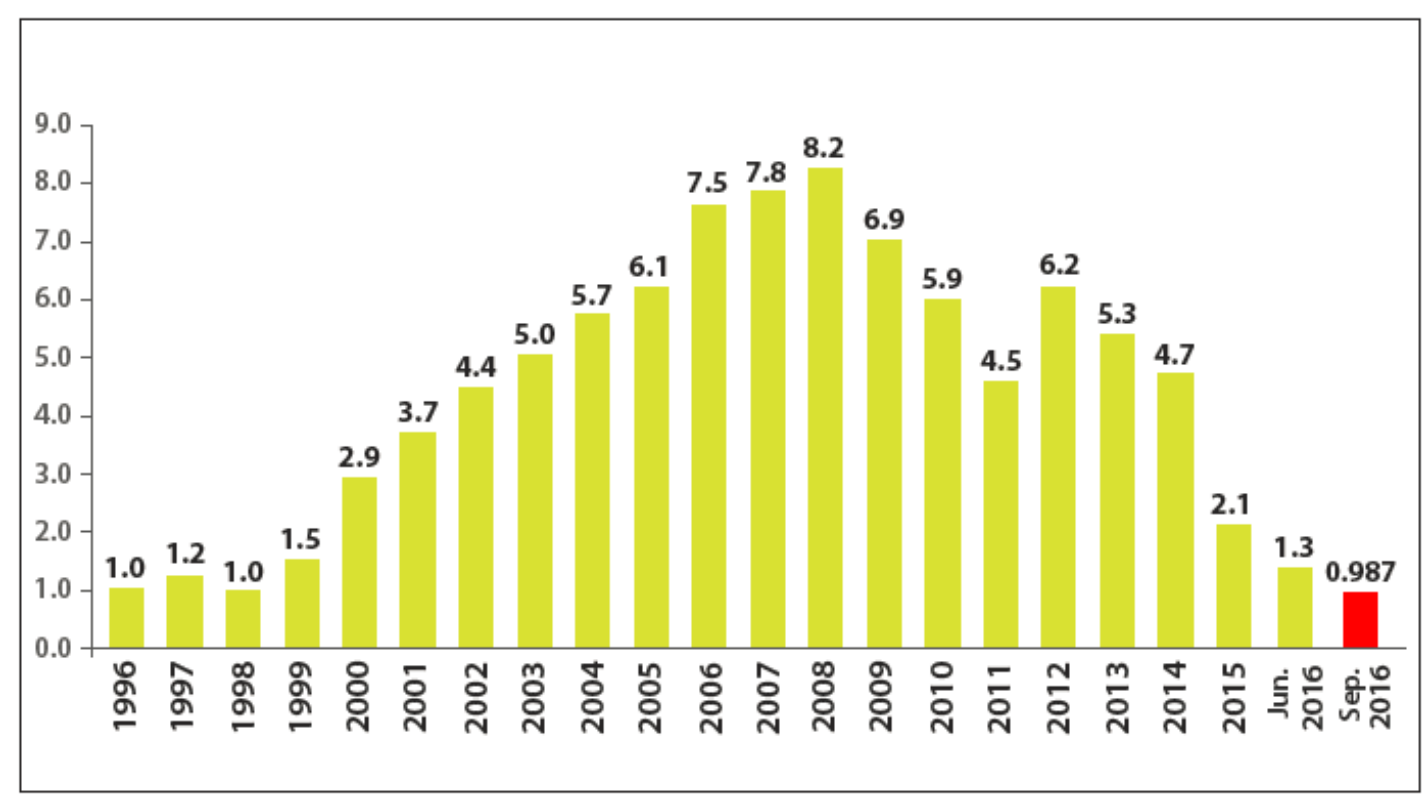

Figure (6). Yemen Foreign Reserves decline 2016

Resource (CentralBank, 2017)

In 2016 Yemen legitimate government has transfer the central bank from Sanaa to Aden which lead to more deterioration of economy. Central Bank lose its weapons the foreign reserve to cover the needs; hence the value of Yemen maliciously increased.

In 2018 the value of Rail has decreased in contrast with the dollar from 214 in 2010 to be 600, which increase the inflation and caused famine.

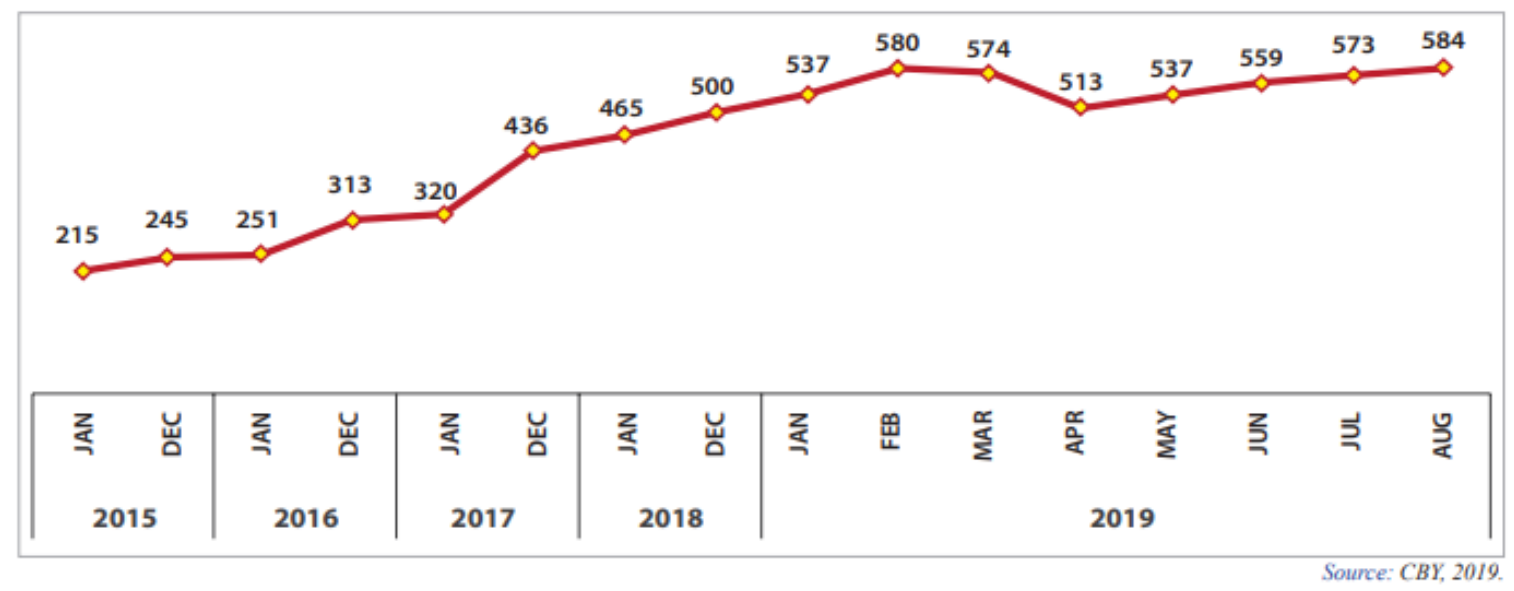

Figure (7). Exchange Rate 2015 -2019 August 


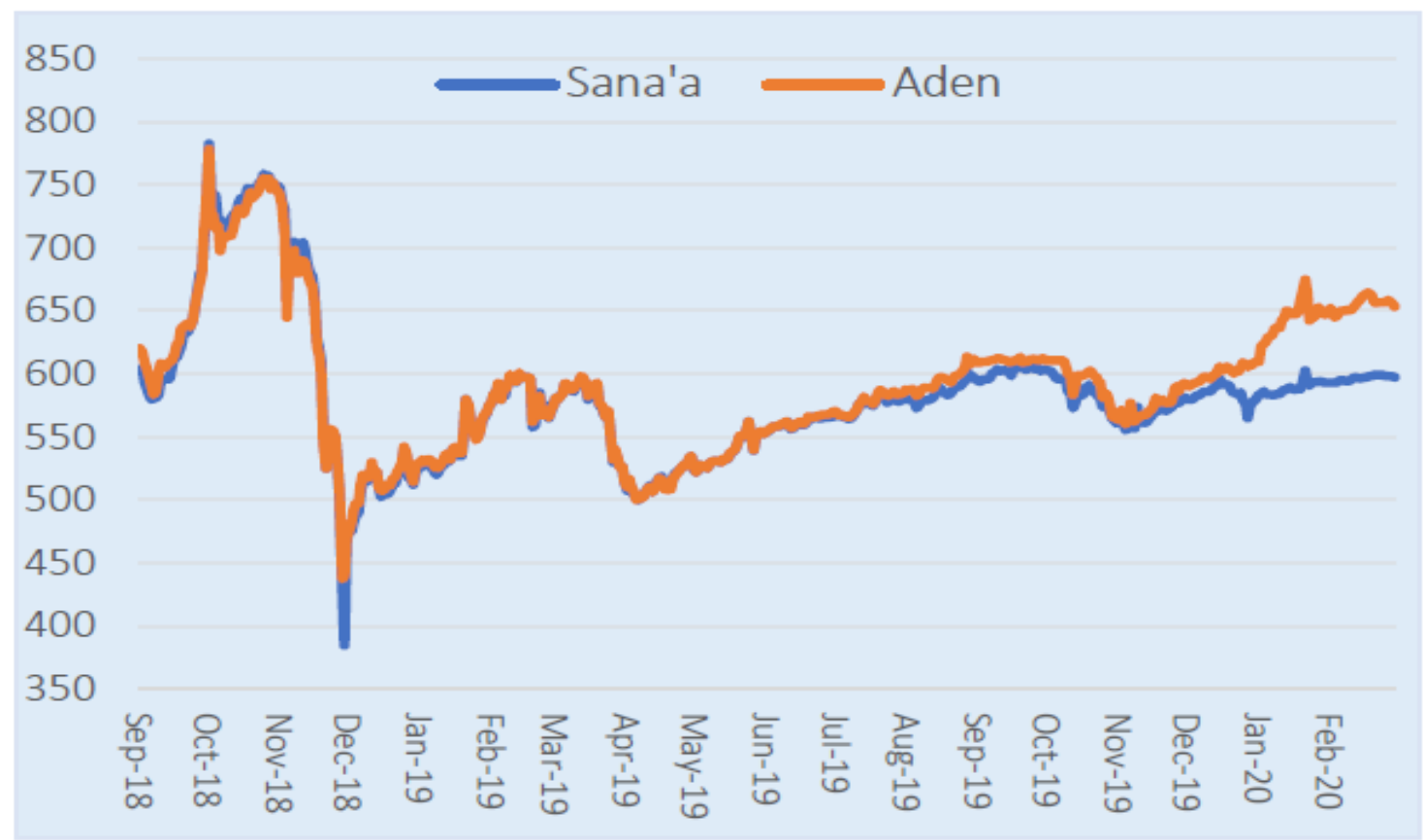

Source: Data collected from Informal exchange rate markets and staff estimates.

Figure (8). The Market Two Exchange Rate In Two Central Bank

Due to erroneous economic policies such as lifting of subsidies on oil supplies, the people felt exploited and this lead to a coup. Beginning with the transfer of the central bank, the floating of the exchange rate, the inability of the central bank to intervene to protect the local currency due to the entry into force of foreign reserves, the presence of a bank in Sana'a, the spread of exchange shops, the non-export of oil as a source of foreign income, intransigence of the coup in the north of the country are some of the factors that we long term and immediate causes of the war.

A combination of factors and the continuation of the devastation of the war led to the further deterioration of the country in all aspects severely deteriorating leaving standards communities with disease and famine.

All these challenges left people under what the United Nation call it the greatest humanitarian crises in the modern era. Short table describe the situation to date 


\section{Macrothink}

Journal of Public Administration and Governance

Table (2).

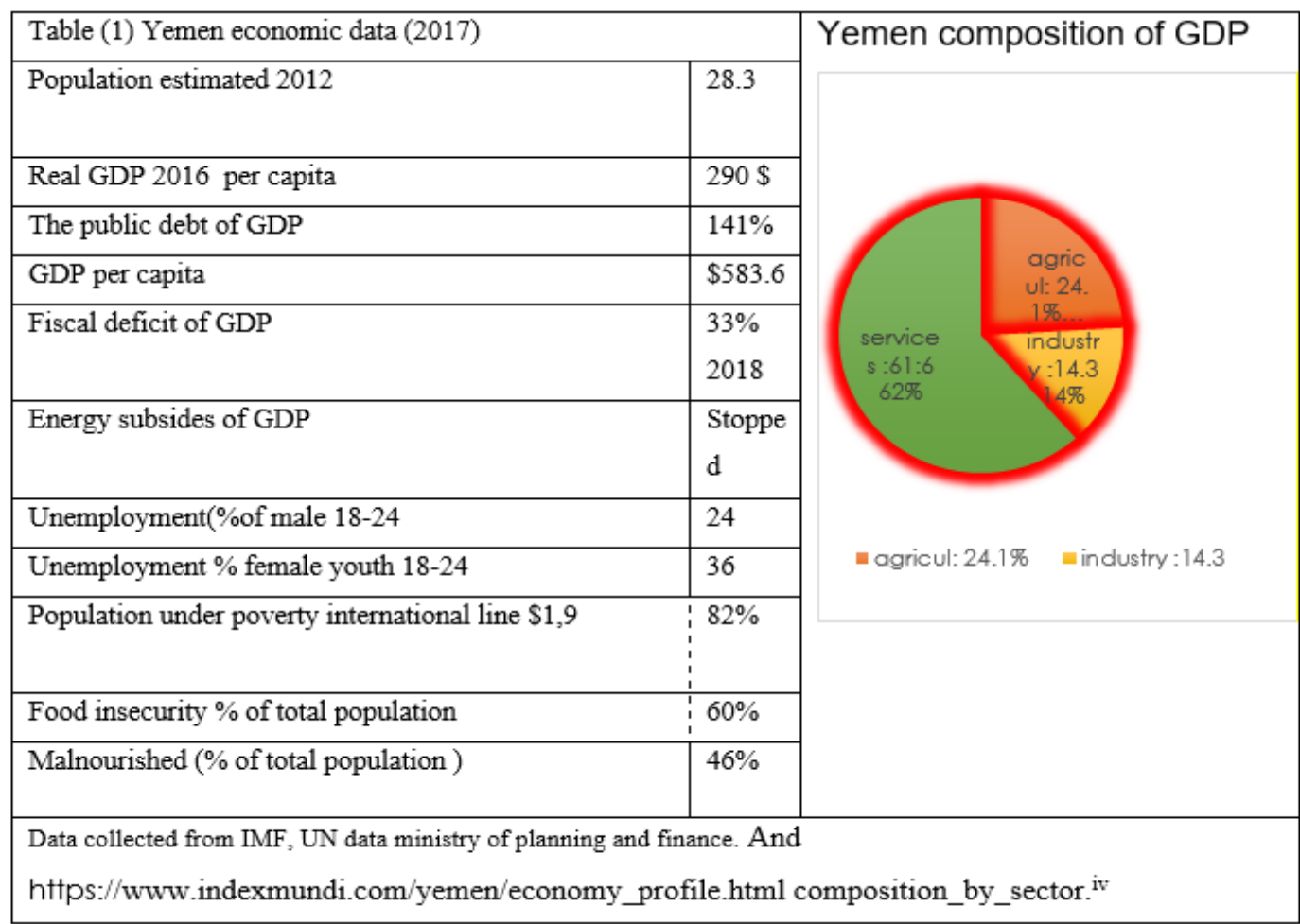

\section{Methodology: Model and Data}

Data are gathered from different resources World Bank, Yemen Central Bank, Yemen statistical centre, correlation and linear regression to identify the relationship implemented. Adding political instability to the gross domestic production to see how it influence the country productivity. The influence of that with regard to the inflation when there is a shortage in productivity and ineffective financial and monetary policies, as known less productivity with much money supply will result in high inflation. We also include the investment as it relationship with instability is clear which will result in healthy economy.

The function of the Model is:

$\mathrm{Y}=\alpha+\beta \times 1+\beta \times 2+\beta \times 3+\beta \times 4+\mathrm{Ue}$

$\mathrm{Y}$ is GDP represent economic growth

$\alpha=.05$

$\beta=$ parameter

$\mathrm{X} 1=$ inflation

$\mathrm{X} 2=$ saving

$\mathrm{X} 3=$ per capita income

$\mathrm{X} 4=$ Political instability. We used this indicators as representative of productivity of the 
country because income per capita, what population earning, and saving, and how, the income effected by inflation. SPSS data analysis program 25 used to conduct the analysis.

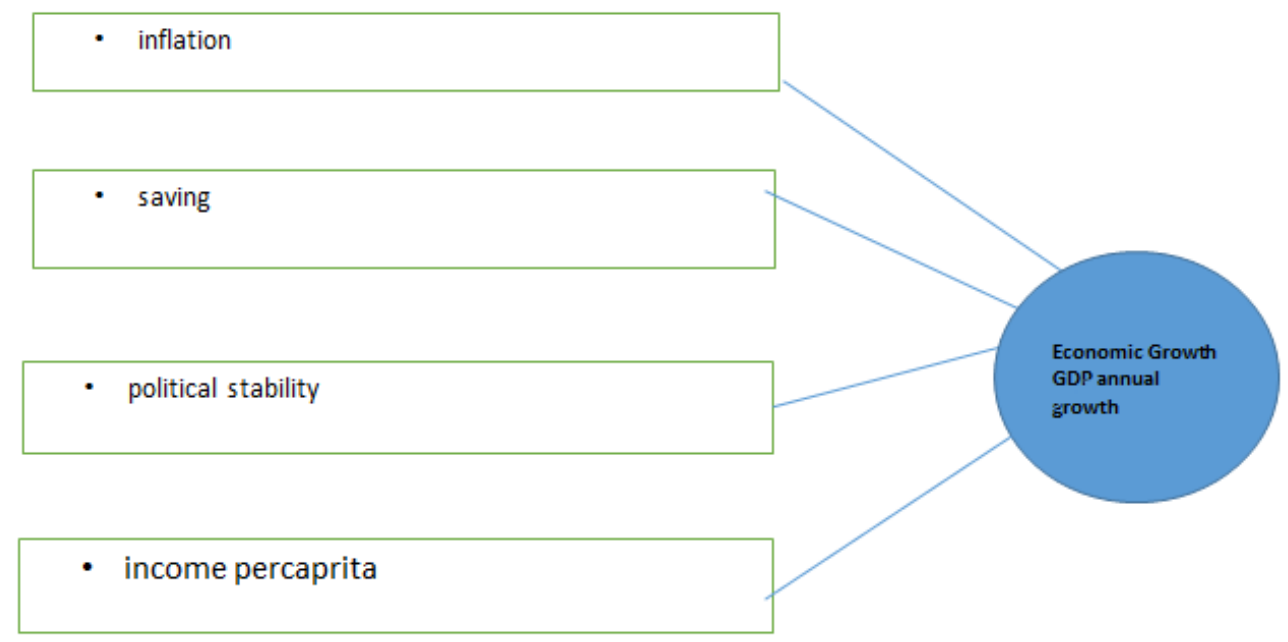

Figure (9). Model of study

Resources, researcher based on (Aisen \& Veiga, 2005; Alesina et al., 1996; Sweidan, 2016)

\section{Analysis and Discussion}

Table (3.1). Normality, Schapiro Wilk

\begin{tabular}{|c|c|c|c|}
\hline \multirow{2}{*}{ Tests of Normality } & \multicolumn{3}{|c|}{ Shapiro-Wilk } \\
\hline & Statistic & Df & Sig. \\
\hline $\inf$ & .965 & 20 & .641 \\
\hline sav & 937 & 20 & .208 \\
\hline incom per & 930 & 20 & .156 \\
\hline Pvest & .901 & 20 & .043 \\
\hline Logcugdpo & .954 & 20 & .438 \\
\hline
\end{tabular}

*. This is a lower bound of the true significance.

\section{a. Lilliefors Significance Correction}

Although, we don't need to check the normality because the data is secondary data and reliable, the above table shows that all variable are normally distributed, only political instability und violence that less than .50 which maybe because of the extreme values but when you look at skewness and kurtosis are between +1.5 and -1.5 so we can say it almost normally distributed.

However, It is important to notice that with the dependent variable (GDP in current US\$), we used a logarithm to reduce the values using the log function (Aisen \& Veiga, 2005; Alalam, 2015; Sweidan, 2016) 
Table (3.2). $\log$ GDP

\begin{tabular}{|l|l|l|l|l|}
\hline \multirow{2}{*}{ Variable } & Test & \multicolumn{2}{|l|}{ Statistic } & \multicolumn{2}{c|}{ Stander error } \\
\hline \multirow{2}{*}{ GDP $\log$ Current \$ } & Skewness & .105 & .512 \\
\cline { 2 - 5 } & Kurtosis & .178 & .992 \\
\hline
\end{tabular}

Table (3.3). Correlations

\section{Correlations}

\begin{tabular}{|c|c|c|c|c|c|c|c|}
\hline & & & logcugdpo & sav & Pvest & $\inf$ & $\begin{array}{l}\text { incom } \\
\text { per }\end{array}$ \\
\hline \multirow[t]{15}{*}{$\begin{array}{l}\text { Spearman's } \\
\text { rho }\end{array}$} & \multirow[t]{3}{*}{ Logcugdpo } & $\begin{array}{l}\text { Correlation } \\
\text { Coefficient }\end{array}$ & 1.000 & $-.720^{* *}$ & $-.804^{* *}$ & -.384 & $.749^{* *}$ \\
\hline & & Sig. (2-tailed) & . & .000 & .000 & .086 & .000 \\
\hline & & $\mathrm{N}$ & 21 & 21 & 21 & 21 & 20 \\
\hline & \multirow[t]{3}{*}{ sav } & $\begin{array}{l}\text { Correlation } \\
\text { Coefficient }\end{array}$ & $-.720^{* * *}$ & 1.000 & $.639^{* * *}$ & -.003 & -.416 \\
\hline & & Sig. (2-tailed) & .000 & . & .002 & .990 & .068 \\
\hline & & $\mathrm{N}$ & 21 & 21 & 21 & 21 & 20 \\
\hline & \multirow[t]{3}{*}{ pvest } & $\begin{array}{l}\text { Correlation } \\
\text { Coefficient }\end{array}$ & $-.804^{* *}$ & $.639^{* *}$ & 1.000 & .117 & $-.513^{*}$ \\
\hline & & Sig. (2-tailed) & .000 & .002 & . & .614 & .021 \\
\hline & & $\mathrm{N}$ & 21 & 21 & 21 & 21 & 20 \\
\hline & \multirow[t]{3}{*}{$\inf$} & $\begin{array}{l}\text { Correlation } \\
\text { Coefficient }\end{array}$ & -.384 & -.003 & .117 & 1.000 & -.272 \\
\hline & & Sig. (2-tailed) & .086 & .990 & .614 & . & .245 \\
\hline & & $\mathrm{N}$ & 21 & 21 & 21 & 21 & 20 \\
\hline & \multirow[t]{3}{*}{ incom per } & $\begin{array}{l}\text { Correlation } \\
\text { Coefficient }\end{array}$ & $.749^{* *}$ & -.416 & $-.513^{*}$ & -.272 & 1.000 \\
\hline & & Sig. (2-tailed) & .000 & .068 & .021 & .245 & . \\
\hline & & $\mathrm{N}$ & 20 & 20 & 20 & 20 & 20 \\
\hline **. Correlat & is significal & $\mathrm{t}$ at the 0.01 leve & led). & & & & \\
\hline
\end{tabular}

Regression Enter Method. 


\section{Macrothink}

Table (3.4). Regression enter method

Model Summary

Model Summary

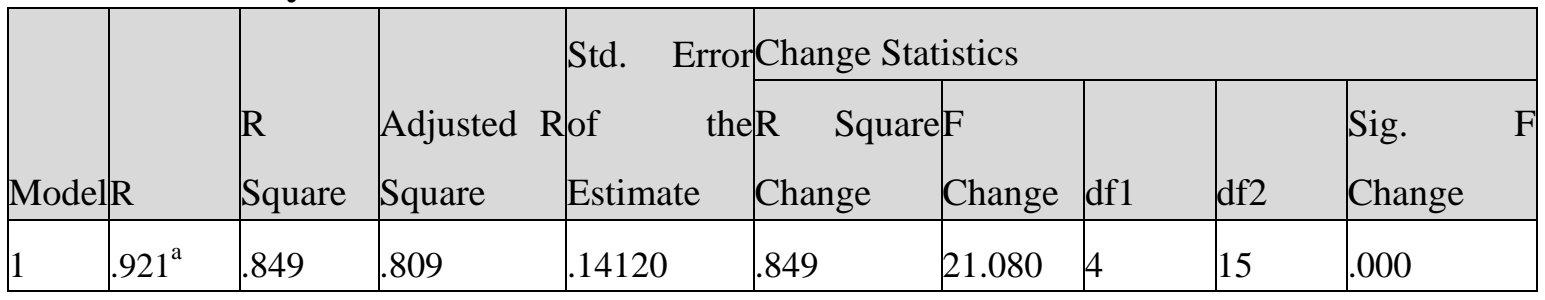

a. Predictors: (Constant), pvest, inf, incom per, sav

b. Dependent Variable: logcugdpo

Table (3.5). ANOVAa

\section{ANOVA $^{\text {a }}$}

\begin{tabular}{|l|l|l|l|l|l|l|}
\hline \multicolumn{2}{|l|}{ Model } & Sum of Squares & Df & Mean Square & F & Sig. \\
\hline \multirow{3}{*}{1} & Regression & 1.681 & 4 & .420 & 21.080 & $.000^{\mathrm{b}}$ \\
\cline { 2 - 8 } & Residual & .299 & 15 & .020 & & \\
\cline { 2 - 7 } & Total & 1.980 & 19 & & & \\
\hline
\end{tabular}

a. Dependent Variable: logcugdpo

b. Predictors: (Constant), pvest, inf, incom per, sav

Table (3.6). Unstandardized Coefficients

\begin{tabular}{|c|c|c|c|c|c|}
\hline \multirow[t]{2}{*}{ Model } & \multicolumn{2}{|c|}{ Unstandardized Coefficients } & \multirow{2}{*}{\multicolumn{2}{|c|}{ Sig .P.V }} & \multirow[b]{2}{*}{ VIF } \\
\hline & $\mathrm{R}^{2}$ & B & & & \\
\hline (Constant) & \multirow[b]{3}{*}{.849} & 9.886 & 000 & & \\
\hline $\operatorname{Inf}$ & & -.007 & .013 & 1.113 & \\
\hline Sav & & -.011 & .006 & 1.679 & \\
\hline incom per & & .000 & .010 & 1.264 & \\
\hline Pvest & & -.141 & .030 & 1.629 & \\
\hline
\end{tabular}

Regression model above show our main targeted variable political instability alone, researcher notice that, from $\mathrm{R}$ value $\mathrm{R}=.669, \mathrm{R} 2.448$ and adjusted $\mathrm{R}, 419$ and $\mathrm{P} . \mathrm{V}$ value is significance too, Which indicate that political instability play a major role in economy GDP. Also, the variation inflation factor is between 1 and 10 and that confirm no multicollinearity which is an accepted value (Gelman \& Hill, 2007).

Best and full Model: Y = 9.886 - .007-.011 X2 + .000 X3-.141X4.

Consequently, we reject the null hypothesis that political instability has no impact in 
economic growth represented in GDP, the result indicate all variables has influence in growth including political instability which logic. It also shows that political instability has the more influence.

Regression Stepwise Method

Table (3.7) Regression stepwise

\begin{tabular}{|l|l|l|l|l|}
\hline \multicolumn{2}{|l|}{ Model Summary } & & & \\
\hline Model & R & R Square & Adjusted R Square & Std. Error of the Estimate \\
\hline 1 & $.739^{\mathrm{a}}$ & .546 & .521 & .22346 \\
\hline 2 & $.851^{\mathrm{b}}$ & .725 & .692 & .17908 \\
\hline 3 & $.890^{\mathrm{c}}$ & .791 & .752 & .16070 \\
\hline 4 & $.921^{\mathrm{d}}$ & .849 & .809 & .14120 \\
\hline
\end{tabular}

a. Predictors: (Constant), sav

b. Predictors: (Constant), sav, incom per

c. Predictors: (Constant), sav, incom per, inf

d. Predictors: (Constant), sav, incom per, inf, pvest

Table (3.8). Anova

\begin{tabular}{|c|c|c|c|c|c|c|}
\hline \multicolumn{7}{|c|}{ ANOVA $^{a}$} \\
\hline \multicolumn{2}{|c|}{ Model } & \multirow{2}{*}{$\begin{array}{l}\text { Sum of Squares } \\
1.081\end{array}$} & \multirow{2}{*}{$\begin{array}{l}\text { Df } \\
1\end{array}$} & \multirow{2}{*}{$\begin{array}{l}\text { Mean Square } \\
1.081\end{array}$} & \multirow{2}{*}{$\begin{array}{l}F \\
21.659\end{array}$} & \multirow{2}{*}{$\begin{array}{l}\text { Sig. } \\
.000^{\mathrm{b}}\end{array}$} \\
\hline 1 & Regression & & & & & \\
\hline & Residual & .899 & 18 & .050 & & \\
\hline & Total & 1.980 & 19 & & & \\
\hline \multirow[t]{3}{*}{2} & Regression & 1.435 & 2 & .718 & 22.373 & $.000^{\mathrm{c}}$ \\
\hline & Residual & .545 & 17 & .032 & & \\
\hline & Total & 1.980 & 19 & & & \\
\hline \multirow[t]{3}{*}{3} & Regression & 1.567 & 3 & .522 & 20.226 & $.000^{\mathrm{d}}$ \\
\hline & Residual & .413 & 16 & .026 & & \\
\hline & Total & 1.980 & 19 & & & \\
\hline \multirow[t]{3}{*}{4} & Regression & 1.681 & 4 & .420 & 21.080 & $.000^{\mathrm{e}}$ \\
\hline & Residual & .299 & 15 & .020 & & \\
\hline & Total & 1.980 & 19 & & & \\
\hline
\end{tabular}

a. Dependent Variable: logcugdpo

b. Predictors: (Constant), sav

c. Predictors: (Constant), sav, incom per 
d. Predictors: (Constant), sav, incom per, inf

e. Predictors: (Constant), sav, incom per, inf, pvest

Table (3.9). Unstandardized Coefficients

\begin{tabular}{|c|c|c|c|c|}
\hline \multirow{2}{*}{\multicolumn{2}{|c|}{ Model }} & \multicolumn{2}{|c|}{ Unstandardized Coefficients } & \multirow{3}{*}{$\begin{array}{l}\text { Sig.P-V } \\
.000\end{array}$} \\
\hline & & B & $\mathrm{R}^{2}$ & \\
\hline 1 & (Constant) & \multirow[t]{2}{*}{10.330} & \multirow[t]{2}{*}{546} & \\
\hline & Save & & & .000 \\
\hline \multirow[t]{3}{*}{2} & & 9,971 & \multirow[t]{3}{*}{.725} & .000 \\
\hline & (Save) &,- 016 & & .000 \\
\hline & (income ) &, 000 & & .004 \\
\hline \multirow[t]{4}{*}{3} & (Constant) & 10,132 & \multirow[t]{4}{*}{.791} & .000 \\
\hline & (Save) & -.016 & & .000 \\
\hline & (income ) &, 000 & & .011 \\
\hline & (Inf &,- 006 & & .038 \\
\hline \multirow[t]{5}{*}{4} & (Constant) & 9,886 & \multirow[t]{5}{*}{.849} & .000 \\
\hline & (Save) &,- 011 & & .000 \\
\hline & Incom per &, 000 & & .010 \\
\hline & (Inf &,- 007 & & .003 \\
\hline & Pvest.) &,- 141 & & .030 \\
\hline
\end{tabular}

Thus, the stepwise regression, the results of which are shown in tables 3,7, 3.8, and 3.9 ,confirms the impact of inflation ,income per capita ,the saving manner, and finally political instability and violence in Growth with R2 in the four models with values of $.546,725,791$ and the full Model ,849 respectively, at the significance levels of .010, .003, and .030 , also respectively. This enables us to reject the null hypotheses saying no impact of the four independent variables.

\section{Conclusion}

This paper highlights the influence of political instability on the Yemen economy. The data utilized from different resources using panel data to analyze the connection. From the literature, instability harms the economy. This study refers to many opinions, all have clarified, and the deterioration of the economy comes from mostly because of the instability 
and the conflict the countries experienced. We used the political instability definition of the World Bank. For the empirical part, the research adopted the political instability from worldwide data from the World Bank Group includes the index-like absence of violence, civil war rebellion political assassination violent demonstration, insurgency, absence of torture terrorism religious, and ethnic conflict. The searchers suggested adding an index to the variables, which is the intervention of such a country in others for personal gain and interests. Empirically, the researcher utilizes the correlation to test the existence of a correlation between the selected and the multiple regression techniques to test the impact.

The result shows a strong negative correlation between political and GDP growth at .669, which means that if political instability increased one point it causes the economy to reduce by the same point. This correlation enables the researcher to continue with the regression. The result of the model investigation shows a significant regression with $\mathrm{R}=.92$ and $\mathrm{R} 2$ $=.849$ and adjusted $\mathrm{R}=, 809$. Thus, our model is significant with sig .030 . Therefore, it can be inferred that political instability has a great influence on Yemen's economy. This result is in line with previous studies specifically with underdeveloped countries, which have similar circumstances. The main finding of this study is the situation in Yemen is complex, with multiplayer at the local, regional, and international levels. The conflict between the Houthi Movement and government is rooted in ethnic conflict, and Houthi believes that they are relevant.

\section{Recommendation}

The first recommendation is for all local, regional, and international stakeholder's researcher fined Yemen's instability problems along the history linked to the political regime. Therefore, if there is a real intension for peace and stability in Yemen, we should find a political solution first. The economic file should not be discussed only after the political part. Although Humanitarian organizations help to reduce the famine crises, it is a reason for the continuous conflict and war; Because of many international and local corrupted beneficiaries of wars.

\subsection{To International Organization}

1- There is misunderstanding of the international community to the Yemen society structure. So, they participate in the worsen situation. International organizations and research centers have noted of political instability, in such forms as wars and, ethnic and religious conflicts affects a country. However, they overlook one of the most important indicators related to direct and indirect intervention into the affairs of a sovereign country by other countries for economic expansion and plundering economic resources. Researcher recommends the addition of a facilitator of external interventions to monitor countries for interests in economic expansion.

2- Stability and Peace are pre-requested to economic and development. The situation in Yemen is complex, its civil war, and a war with the coalition, in third part countries represented by Saudi Arabia. Therefore, the peace model must take this into account and include all the parties involved in conflict during peace discussions. 


\subsection{Recommendation to Society}

1. In Yemen, all armed groups fighting should be aware come together themselves sign peace treaty followed by disbarment of all armed forces and under the control of international observers.

2. Yemeni's themselves should accept that the only way for the Yemenis in the north and south to restore the state and stability, turn to secularism to free themselves of autocratic and fraud of religious groups and to rid themselves of autocratic rulers.

3. Increase the Awareness about the nepotism through good quality education, handled the weapons to the government to live in peace and build the country.

\subsection{To Government and Policymakers}

1. Policymakers should locally and internationally consider a comprehensive model of peace in the country with the inclusion of all effective groups to guarantee permanent peace.

2. A peace plan that includes withdrawing weapons from groups while continuing to withdraw weapons from society gradually because the weapon is one of the causes of the conflict Include the county's history in the school curriculum and teach it to future generations so that they are aware of their history.

3. Criminalize the receipt of money from any individual or other countries under any reason and consider it a betrayal worthy of the death penalty.

4. Non-leniency for all those who break the law or attack the state in money or land or human beings and the most severe penalties and the maximum speed without hesitation in the implementation of the law.

5. Strengthen the judicial and security systems and cooperation between them.

6. Restore the role of the private sector to strengthen the economy through policies and procedures to facilitate and activate the private sector role in creating jobs and revenues otherwise, neither government nor private sector can't be alone.

7. War should be stopped because Yemen is a victim of the war between big plays.

8. There should be a big national investment project under the control of foreign and local experienced expert especially Yemeni immigrants because of war.

\subsection{To Academic Sector and Researcher}

1. More research Writing about the Yemeni's dark history of instability and publishing the paper to raise awareness and learn from our history.

\section{References}

Aisen, A., \& Veiga, F. J. (2005). Does political instability lead to higher inflation? A panel data analysis. International Monetary Fund. https://doi.org/10.5089/9781451860689.001

Alalam. (2015). greedy of Saudi in Yemen 
Alesina, A., Özler, S., Roubini, N., \& Swagel, P. (1996). Political instability and economic growth. Journal of Economic growth, 1(2), 189-211. https://doi.org/10.1007/BF00138862

Alfaro, L., Kalemli-Ozcan, S., \& Volosovych, V. (2008). Why doesn't capital flow from rich to poor countries? An empirical investigation. The review of economics and statistics, 90(2), 347-368. https://doi.org/10.1162/rest.90.2.347

AlMayadeenNews. (2015). Media interview with previous president and Head with Almutammer https://www.youtube.com/watch?v=TChYm77RORQ

Almutawakel, Y. Y. (2014). The Social Market Economy in Yemen - Prof. The Social Market Economy In The New Constitution Of Yemen, Sanaa

Alwals, M. (2017). Qater support hoties since 17 year https://yemenvoice.net/news118556.html

Barro, R. J. (1991). A cross-country study of growth, saving, and government. In National saving and economic performance (pp. 271-304). University of Chicago Press.

Benhabib, J., \& Spiegel, M. M. (1994). The role of human capital in economic development evidence from aggregate cross-country data. Journal of Monetary economics, 34(2), 143-173. https://doi.org/10.1016/0304-3932(94)90047-7

Busse, M., \& Hefeker, C. (2007). Political risk, institutions and foreign direct investment. European journal of political economy, 23(2), 397-415. https://doi.org/10.1016/j.ejpoleco.2006.02.003

CentralBank. (2017). FOREIGN RESERV CENTRAL BANK OF YEMEN 2016

CentralBank. (2017). Foreign Reserv Central Bank of Yemen 2016.

CentralBank. (2017). FOREIGN RESERV CENTRAL BANK OF YEMEN 2016.

CNNarabic. (2012). Call to investigate that politicians receive Saudi money. http://archive.arabic.cnn.com/2012/yemen.2011/6/10/yemen.saudi/index.html

Cruz, C. (2018). The Role of UAE in Yemen INTERNATIONAL POLICY DIGESThttps://intpolicydigest.org/2018/03/20/the-uae-s-role-in-yemen/.

Cukierman, A., Edwards, S., \& Tabellini, G. (1989). Seigniorage and political instability. https://doi.org/10.3386/w3199

Daude, C., \& Stein, E. (2007). The quality of institutions and foreign direct investment. Economics \& Politics, 19(3), 317-344. https://doi.org/10.1111/j.1468-0343.2007.00318.x

Easterly, W., \& Rebelo, S. (1993). Fiscal policy and economic growth. Journal of monetary economics, 32(3), 417-458. https://doi.org/10.1016/0304-3932(93)90025-B

Edward, H. (2005). Workshop in Sanaa about how to develop,

Gelman, A., \& Hill, J. (2007). Data analysis using regression and multilevelhierarchical models (Vol. 1). Cambridge University Press New York, NY, USA. 
Hill, G., \& Nonneman, G. (2011). Yemen, Saudi Arabia and the Gulf States: Elite Politics, Street Protests and Regional Diplomacy. Chatham House London, UK.

Hill, G., Salisbury, P., Northedge, L., \& Kinninmont, J. (2013). Yemen: corruption, capital flight and global drivers of conflict. Chatham House.

Hournews. (2012). President Hai acuus Iran http://hournews.net/news-12605.htm

Jong-A-Pin, R. (2009). On the measurement of political instability and its impact on economic growth. European Journal of Political Economy, 25(1), 15-29. https://doi.org/10.1016/j.ejpoleco.2008.09.010

Kaufmann, D., Kraay, A., \& Mastruzzi, M. (2011). The worldwide governance indicators: methodology and analytical issues. Hague Journal on the Rule of Law, 3(2), 220-246. https://doi.org/10.1017/S1876404511200046

Ranga, M., \& Pradhan, P. (2014). Terrorism terrorizes tourism:: Indian tourism effacing myths? IJSSTH, 1(5), 26-39.

Rodrik, D. (1989). Policy uncertainty and private investment in developing countries (0898-2937). https://doi.org/10.3386/w2999

Salisbury, P. (2014). Yemen's Southerners see hope in Houthis' riseAljazira

Salisbury, P. (2015). Yemen and the Saudi-Iranian 'Cold War'. Research Paper, Middle East and North Africa Programme, Chatham House, the Royal Institute of International Affairs, 11 .

Salisbury, P. (2017). Yemen: national chaos, local order. Chatham House.

Schneider, F., \& Frey, B. S. (1985). Economic and political determinants of foreign direct investment. World development, 161-175. https://doi.org/10.1016/0305-750X(85)90002-6

Sweidan, O. D. (2016). Political instability and economic growth: evidence from Jordan. Review of Middle East Economics and Finance, 12(3), 279-300. https://doi.org/10.1515/rmeef-2015-0025

Tabassam, A. H., Hashmi, S. H., \& Rehman, F. U. (2016). Nexus between political instability and economic growth in Pakistan. Procedia-Social and Behavioral Sciences, 230, 325-334. https://doi.org/10.1016/j.sbspro.2016.09.041

Tornell, A., \& Velasco, A. (1992). The Tragedy of the Commons and Economic Growth: Why Does Capital Flow from Poor to. Journal of Political Economy, 100(6). https://doi.org/10.1086/261858

World, B. (2017). Yemen's Economic Outlook - October 2017.

Worldbank. (2017). world development indicators.

Yemenpressagency. (2018). Accusing Saudi of paying Money and to some schiekh and ask to 
investigate.

\section{Copyright Disclaimer}

Copyright for this article is retained by the author(s), with first publication rights granted to the journal.

This is an open-access article distributed under the terms and conditions of the Creative Commons Attribution license (http://creativecommons.org/licenses/by/4.0/). 